\title{
PENGARUH PEMBERIAN EKSTRAK ETANOL JAHE MERAH (Zingiber officinale Roxb. Var. Rubrum) TERHADAP SPERMATOZOA EPIDIDIMIS MENCIT (Mus musculus L.) YANG DIINDUKSI SIPROTERON ASETAT
}

\section{EFFECT OF RED GINGER ETHANOL EXTRACT ( Zingiber officinale Roxb . Var . Rubrum ) ON EPIDIDYMAL SPERMATOZOA IN CYPROTERONE ACETATE INDUCED MICE (Mus musculus L.)}

\author{
Pepti Aristiani*, Sutyarso, Hendri Busman \\ Mahasiswa Jurusan Biologi FMIPA Universitas Lampung \\ *e-mail: pepti.aristiani@gmail.com
}

\begin{abstract}
ABSTRAK
Infertilitas merupakan kondisi yang umum ditemukan di Indonesia. Jahe merah (Zingiber officinale Roxb. var. Rubrum) merupakan tumbuhan yang memiliki banyak khasiat di berbagai aspek. Jahe merah memiliki pengaruh yang baik sebagai antioksidan terhadap sel spermatogenik dan parameter sperma pada mencit (Mus musculus L.) jantan yang diinduksi siproteron asetat. Penelitian ini bertujuan untuk mengetahui pengaruh pemberian ekstrak etanol jahe merah terhadap jumlah ,motilitas, morfologi, dan viabilitas spermatozoa. Penelitian ini menggunakan metode Rancangan Acak Lengkap, menggunakan 25 ekor mencit jantan yang dibagi dalam 5 kelompok yaitu Kontrol Normal, K- (diberikan siproteron asetat 1,17mg/ml selama 7 hari), P1, P2 dan P3 (diinduksi siproteron asetat $1,17 \mathrm{mg} / \mathrm{ml}$ selama 7 hari dan ekstrak etanol jahe merah dengan dosis berturut-turut $6 \mathrm{mg} / \mathrm{ml}, 12 \mathrm{mg} / \mathrm{ml}, 24 \mathrm{mg} / \mathrm{ml}$ selama 28 hari). Data yang di peroleh dianalisi menggunakan Analysis of Varian ( ANOVA). Hasil penelitian ini menunjukan bahwa ekstrak etanol jahe merah $6 \mathrm{mg} / \mathrm{ml}, 12 \mathrm{mg} / \mathrm{ml}$, dan $24 \mathrm{mg} / \mathrm{ml}$ dapat meningkatkan jumlah, motilitas, viabilitas dan menurunkan morfologi abnormal spermatozoa yang diinduksi siproteron asetat.
\end{abstract}

Kata kunci : $\quad$ infertilitas, jahe merah, mencit jantan, siproteron asetat, jumlah, morfologi, motilitas viabilitas.

\begin{abstract}
Infertility is a common condition that found in Indonesia. Red ginger (Zingiber officinale Roxb. Var. Rubrum) is a plant that has many benefits in various aspects. Red Ginger has a good effect as an antioxidant against spermatogenic cells and sperm parameters on male mice (Mus musculus L.) induced by cyproterone acetate. This study aimed to determine the influence of red ginger ethanol extract to the quantity, motility, morphology, and viability of spermatozoa. This study uses a completely randomized design, using 25 male mice were divided into 5 groups: Normal Control, K- (given cyproterone acetate $1,17 \mathrm{mg} / \mathrm{ml}$ for 7 days), P1, P2 and P3 (cyproterone acetate induced $1.17 \mathrm{mg} /$ day for 7 days and red ginger ethanol extract with successive doses of $6 \mathrm{mg} / \mathrm{ml}, 12 \mathrm{mg} / \mathrm{ml}, 24 \mathrm{mg} / \mathrm{ml}$ for 28 days). The data analyzed using Analysis of Variants (ANOVA). The results of this study showed that the ethanol extract of red ginger $6 \mathrm{mg} / \mathrm{ml}, 12 \mathrm{mg} / \mathrm{ml}$ and $24 \mathrm{mg} / \mathrm{ml}$ could increase the quantity, motility, viability and morphology lowering induced abnormal spermatozoa cyproterone acetate.
\end{abstract}

Keyword: infertility, red ginger, male mice, cyproterone acetate, quantity, morphology, viability, motility.

\section{PENDAHULUAN}

Kasus infertilitas pada saat ini banyak ditemukan di Indonesia, infertilitas terjadi tidak hanya pada wanita, tetapi juga pria. Dari keseluruhan angka infertilitas, hampir 50\% terjadi pada pria. Secara garis besar, pasangan yang mengalami infertilitas akan menjalani proses panjang dari evaluasi dan pengobatan, dimana proses ini dapat menjadi beban fisik dan psikologis bagi pasangan infertilitas (Hestiantoro et al., 2013). Untuk menentukan tingkat infertilitas pada pria salah satunya adalah melalui pemeriksaan kualitas spermatozoa. 
Penurunan kualitas spermatozoa yang dihasilkan oleh testis dapat dicegah dengan meminimalisir produksi perooksidan atau dengan meningkatkan senyawa antioksidan yang ada di dalam tubuh. Reaktivitas radikal bebas dapat diredam dengan mengkonsumsi makanan atau minuman yang mengandung antioksidan. Antioksidan berfungsi untuk mensetabilkan radikal bebas dengan melengkapi kekurangan elektron yang dimiliki radikal bebas dan menghambat terjadinya reaksi berantai dari pembentukan radikal bebas baru yang dapat menimbulkan stres oksidatif (Hariyatmi, 2004).

Tanaman Jahe (Zingiber officinale Rosc.) merupakan rempah-rempah Indonesia yang mudah ditemuka di pasar-pasar dan sangat penting dalam kehidupan sehari-hari, terutama dalam bidang kesehatan. Jahe merupakan tanaman obat yang kaya akan khasiat bagi kesehatan, rimpang jahe banyak dicari karena memiliki khasiat sebagai obat-obatan. Pemanfaatan tanaman obat telah banyak dilakukan sejak lama untuk mencegah maupun menyembuhkan penyakit. jahe memiliki senyawa aktif fenolik seperti, gingerol, shagaol, zingeron, ginggerdiol, dan zingibren yang terbukti memiliki aktivitas antioksidan. Jahe juga dilaporkan memiliki aktivitas androgenik karena mampu meningkatkan konsentrasi hormon testosteron dalam serum (Kamtchouing et al., 2002). Hormon testosteron berfungsi untuk mengontrol proses spermatogenesis, memelihara sel sertoli, dan berperan dalam menentukan kualitas spermatozoa.
Penurunan kualitas spermatozoa dapat disebabkan oleh berbabagai faktor, diantaranya hormon yang mempengaruhi proses reproduksi bekerja secara optimal. Hormon testosterone berfungsi untuk mengontrol proses spermatogenesis. Siproteron asetat adalah obat golongan anti androgen yang memiliki efek mengganggu proses spermatogenesis pada pria. Obat ini merupakan salah satu obat yang digunakan sebagai induksi terjadinya infertilitas pada pria. Obat ini termasuk golongan agen antiandrogen yang biasa dipakai untuk terapi hirsutisme pada wanita (IAI, 2012). Siproteron asetat juga dapat dipakai sebagai terapi kanker prostat pada pria (British National Formulary, 2012).

\section{METODE PENELITIAN}

Penelitian ini menggunakan Rancangan Acak Lengkap (RAL) dengan 5 kelompok perlakuan dengan pengulangan sebanyak 5 kali. Kelompok pertama digunakan sebagai kontrol normal, kelompok kedua digunakan sebagai kontrol negatif yang diberikan siproteron asetat $1,17 \mathrm{mg}$ selama 7 hari, kelompok ketiga, keempat dan kelima diberikan siproteron asetat $1,17 \mathrm{mg}$ selama 7 hari dan diberikan ekstrak etanol jahe merah dengan dosis $6 \mathrm{mg} / \mathrm{ml}, 12$ $\mathrm{mg} / \mathrm{ml}, 24 \mathrm{mg} / \mathrm{ml}$ selama 28 hari.

Perlakuan diberikan selama 35 hari berdasarkan siklus spermatogenik mencit yang berlangsung selama 35 hari (Rugh,1968). Sedangkan induksi siproteron asetat dilakukan pada hewan uji selama 7 hari (Zade et al., 2013). Pemberian ekstrak jahe merah diberikan setiap hari selama 28 hari. Setelah 35 hari perlakuan, masing- 
masing hewan coba dikorbankan dengan cara dislokasi leher dan selanjutnya dibedah. Kemudian organ kauda epididimis diambil dan diletakkan ke dalam cawan petri yang berisi $\mathrm{NaCl}$ 0,9\%. Selanjutnya cauda epididimis dimasukkan ke dalam gelas arloji yang berisi 1 $\mathrm{ml} \mathrm{NaCl}$ 0,9\%, kemudian bagian proksimal cauda dipotong sedikit dengan gunting lalu cauda ditekan dengan perlahan hingga cairan sekresi keluar dan tersuspensi dengan $\mathrm{NaCl}$ 0,9\%. Suspensi spermatozoa dari cauda epididimis yang telah diperoleh dapat digunakan untuk pengamatan yang meliputi jumlah, motilitas, viabilitas, morfologi spermatozoa.

Penghitungan jumlah spermatozoa dengan menggunakan Improved Neubeur dibawah mikroskop cahaya dengan perbesaran 100 kali. Hemositometer diletakkan dan dihitung jumlah spermatozoa pada kotak atau bidang A, B, C, atau D. Hasil perhitungan jumlah spermatozoa kemudian dimasukkan ke dalam rumus penentuan jumlah spermatozoa/ml suspensi sekresi kauda epididimis: Jumlah spermatozoa = $\mathrm{n} / 0,1 \times$ pengenceran $\times 10^{3} \mathrm{juta} / \mathrm{ml}$; dimana $\mathrm{n}=$ Jumlah spermatozoa yang dihitung pada kotak A, B, C, atau D ( Gandasoebrata dalam Maisuri, 2013). Presentase spermatozoa motil dihitung dalam satu luasan bidang pandang menggunakan mikroskop cahaya pada pembesaran 100x dengan menaksir spermatozoa yang bergerak progresif dari keseluruhan lapang pandang dan daerah taksir, kemudian dikali 100\%. Penilaian dilakukan dengan menghitung persentase spermatozoa yang pergerakannya progresif maju ke depan dibandingkan dengan seluruh yang teramati (bergerak maupun tidak).
Pemeriksaan morfologi

spermatozoa dilakukan dengan membuat preparat apus (metode smear). Suspensi sperma kemudian diwarnai dengan Eosin, kemudian diamati dibawah mikroskop dengan perbesana $10 \times 40$. Pengamatan dilakukan terhadap 100 spermatozoa, kemudian dibandingkan antara spermatozoa normal dengan yang tidak normal. Pemeriksaan viabilitas spermatozoa dilakukan dengan cara pengecatan dengan zat warna Eosin, pengamatan sediaan di bawah mikroskop dengan perbesaran $10 \times 40$ dihitung per 100 spermatozoa. Spermatozoa yang hidup tidak berwarna, sedangkan yang mati berwarna merah, kemudian hasilnya dinyatakan dalam persentasi. Pada setiap kelompok, data yang terkumpul dianalisis menggunakan program SPSS versi 20 dengan menggunakan uji One Way Anova untuk menguji perbedaan rerata pada kelompok perlakuan dan kelompok kontrol.

\section{HASIL DAN PEMBAHASAN}

\section{Jumlah spermatozoa}

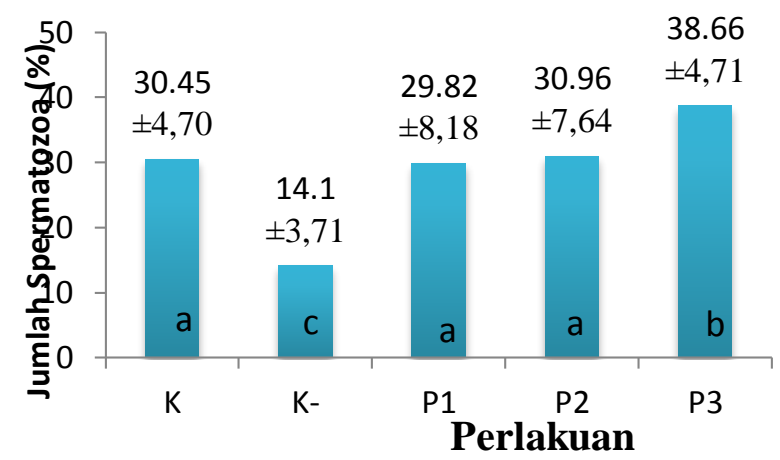

- K : Kontrol, K- : Kontrol Negatif, P1 : 6mg/ml, $\mathrm{P} 2: 12 \mathrm{mg} / \mathrm{ml}, \mathrm{P} 3: 24 \mathrm{mg} / \mathrm{ml}$

Gambar 1. Grafik Rerata jumlah spermatozoa Mencit Jantan. 
Berdasarkan grafik pada gambar 1 di atas, menunjukkan bahwa terdapat penurunan rerata persentase jumlah spermatozoa antara kelompok kontrol (-) terhadap kelompok kontrol normal dan terdapat peningkatan rerata persentase jumlah spermatozoa pada kelompok P1, P2 dan P3 terhadap kelompok normal dan kelompok kontrol (-) yang hanya diberi siproteron asetat.

\section{Motilitas spermatozoa}

Berdasarkan grafik pada Gambar 2, menunjukkan bahwa terdapat penurunan rerata yang signifikan persentase motilitas spermatozoa antara kelompok kontrol(-) terhadap kelompok kontrol normal, serta kelompok P1 terhadap kelompok normal dan terdapat sedikit peningkatan rerata persentase motilitas spermatozoa pada kelompok P2 dan P3 terhadap kelompok kontrol (-).

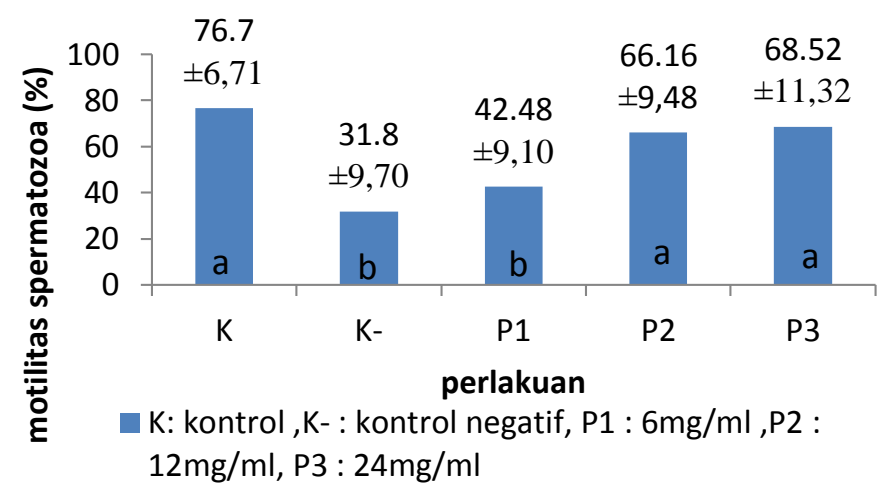

Gambar 2. Grafik Rerata Motilitas spermatozoa Mencit Jantan.

\section{Morfologi spermatozoa}

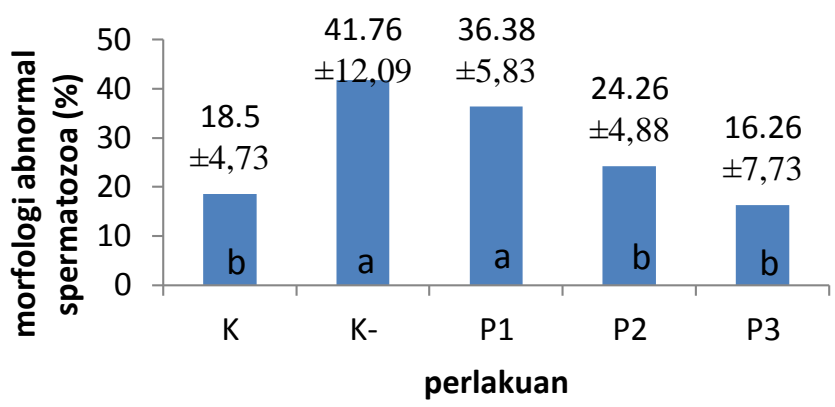

- K: kontrol, K- : Kontrol negatif, P1 : $6 \mathrm{mg} / \mathrm{ml}, \mathrm{P} 2$ : $12 \mathrm{mg} / \mathrm{ml}, \mathrm{P} 3: 24 \mathrm{mg} / \mathrm{ml}$

Gambar 3. Grafik Rerata Morfologi Abnormal Mencit Jantan.

Berdasarkan grafik pada gambar 3 di atas, menunjukkan bahwa terdapat peningkatan yang signifikan rerata persentase jumlah morfologi abnormal spermatozoa antara kelompok kontrol (-) terhadap kelompok kontrol normal, serta pada kelompok P1, P2 dan P3 menunjukan penurunan jumlah morfologi spermatozoa terhadap kelompok K(-).

\section{Viabilitas Spermatozoa}

Berdasarkan grafik pada Gambar 4, menunjukkan bahwa terdapat penurunan rerata yang signifikan persentase viabilitas spermatozoa antara kelompok kontrol(-) terhadap kelompok kontrol normal, serta terdapat sedikit peningkatan rerata persentase viabilitas spermatozoa pada kelompok P1, P2 dan P3 terhadap kelompok kontrol (-), pada P3 rerata viabilitas spermatozoa lebih banyak dibandingkan dengan kelompol normal $\mathrm{K}$ yang hanya diberi pakan dan minum. 


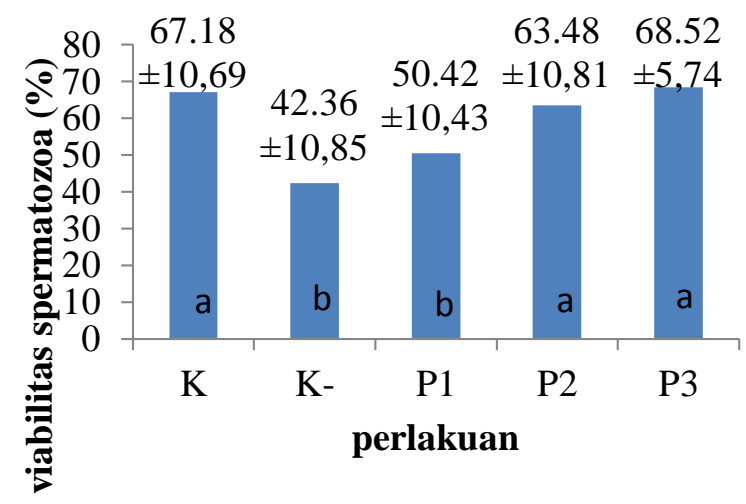

- K: kontrol, K-: kontrol negatif, P1 : $6 \mathrm{mg} / \mathrm{ml}, \mathrm{P} 2: 12 \mathrm{mg} / \mathrm{ml}, \mathrm{P} 3: 24 \mathrm{mg} / \mathrm{ml}$

Gambar 4. Grafik Rerata Viabilitas spermatozoa Mencit Jantan.

\section{PEMBAHASAN}

Penurunan jumlah, motilitas, viabilitas dan meningkatnya morfologi abnormal spermatozoa disebabkan oleh induksi siproteron asetat. Penggunaan siproteron asetat pada pria menyebabkan adanya pengganti hormon androgen akibat kekurangan androgen yang disebabkan oleh efek anti androgen pada siproteron asetat. Siproteron asetat menyebabkan penurunan spermatogenesis yang disebabkan oleh efek langsungnya terhadap testis dimana siproteron asetat menghambat ikatan antara testosterone dan dehidrotestosteron dengan reseptor androgenny (Rajalakshmi, 2005).

Jahe merah memiliki kandungan aktif yang berfungsi sebagai antioksidan diantaranya gingerol, shogaol, zingibrene, gingerdiol, dan zingerone. Zat-zat tersebut mampu mencegah kerusakan yang diakibatkan oleh radikal bebas. Aktivitas enzim-enzim antioksidan endogen seperti superoxide dismutase, catalase, dan gluthtione peroxides pada jahe mampu mencegah terjadinya peroksidasi lipid (Khaki dkk., 2009).

Jahe merah memiliki senyawa fenolik antara lain zingeron, shagaol dan gingerol yang terdapat dalam oleoresin dan memiliki sifat oksidatif. Zat antioksidan yang kuat dan mampu mengurangi serta mencegah terbentuknya radikal-radikal bebas, sehingga jahe merah telah dianggap sebagai obat herbal yang aman dengan efek samping yang sangat minimal. Sebagai hasil dari aktivitas antioksidannya, jahe akan memacu aktivitas androgenik untuk organ testis sebagai hasil dari peningkatan hormon $\mathrm{LH}, \mathrm{FSH}$, dan testosteron (Ali dkk., 2008).

Jahe merah juga memiliki kandungan khusus yaitu arginin yang merupakan asam amino nonesensial. Arginin merupakan prekursor dari Nitrit Oxide (NO) endogen. Arginin dipecah oleh suatu enzim bernama Nitrit Oxide Synthases (NOS) menjadi citrulline dan NO. Nitrit Oxide yang dihasilkan arginin ini mempunyai dua peranan penting terhadap spermatozoa. Yang pertama, meningkatkan motilitas spermatozoa dengan cara meningkatkan metabolism rate serta kadar kalsium dalam mitokondria dan menghasilkan ATP lebih banyak. Pada akhirnya ATP ini digunakan sebagai sumber energi motilitas spermatozoa. Yang kedua yaitu melindungi membran aksonema dari proses peroksidasi lipid karena keadaan stres oksidatif (Srivastava dkk., 2006).

Dapat dikatakan bahwa pemberian ektrak etanol jahe merah dapat menurunkan abnormalitas spermazoa, meningkatkan jumlah, motolitas dan viabilitas spermatozoa yang disebabkan oleh 
radikal bebas akibat induksi siproteron asetat. Hal ini sesuai dengan hasil penelitian Septina (2002) bahwa, antioksidan pada jahe dapat digunakan untuk menghambat terjadinya peroksidasi lipid. Penghambatan peroksidasi lipid oleh senyawa antioksidan jahe dilakukan dengan cara mendonasikan radikal hidrogen kepada senyawa radikal bebas, sehingga radikal bebas menjadi lebih stabil dan tidak merusak. Akibat senyawa radikal bebas yang sudah stabil, maka kerusakan sel sertoli dan sel leydig dapat terhindari, sehingga proses spermatogenesis kembali normal dan konsentrasi sperma yang dihasilkan meningkat.

\section{KESIMPULAN}

Dari hasil penelitian yang didapatkan dapat disimpulkan bahwa pemberian ekstrak etanol jahe merah dapat meningkatkan jumlah, motilitas dan viabilitas spermatozoa, serta dapat menurunkan abnormalitas spermatozoa mencit jantan yang diinduksi oleh siproteron asetat.

\section{DAFTAR PUSTAKA}

Ali, BH, Blunden G., Tanira MO., Nemmar A. 2008. Some Phytochemical Pharmacological and Toxicological Properties of Ginger (Zingiber officinale Roscoe): a review of recent research. Food Chem Toxicol (46) hal 409-420.

British National Formulary. 2012. Cyproterone Acetate. British Medical Association and Royal Pharmaceutical Society of Great Britain. London.

Hariyatmi. 2004. Kemampuan Vitamin E sebagai Aantioksidan terhadap Radikal Bebas Pada Lanjut Usia. MIPA, 14(1). 52-60.

Hestiantoro, A., Wiweko, B., Pratama, G., \& Yusuf, D (Eds). 2013. Konsensus penanganan infertilitas.
Ikatan Apoteker Indonesia. 2012. Informasi Spesialite Obat. Jakarta: IAI

Kamtchouing, P., Fandio, G Y M., Dimo, T. and Jatsa, H.B. 2002. Evaluation of Androgenic Activity of Zingiber officinale and Penta diplan drabrazzeanain Male Rats. Juornal Andrology. 4 : 299-30

Khaki, A., Fathiazad, F. and Nouri, M. 2009. The effects of gingger on spermatogenesis and sperm parameters of rats. Iranian Journal of Reproductive Medicine. 7 (1): 7-12.

Maisuri, RA. 2013. Pengaruh Pemberian Ekstrak Jahe Merah (Zingiber Officinale Roxb. Var Rubrum) dan Zinc (Zn) Terhadap Jumlah, Motilitas, dan Morfologi Spermatozoa pada Tikus Putih (Rattus norvegicus) Jantan Dewasa Strain Sprague Dawley. Medical Journal of Lampung University (2).

Rajalakshmi, M. 2002. Male contraception: expanding reproductive choice. India Institute of Medical Science. Indian J. Experimantal Biology. 43 pp 1032-1041

Rugh ,R. 1968. The Mouse: Its Reproduction and Developmental. Burgess Publishing Company. pp 1-23. Minneapolis.

Septina. 2002. Aktivitas Antioksidan Ekstrak Dikhlorometana dan Air Jahe (Zingiber officinale Rosc) pada Asam Linoleat. Jurnal Teknologi dan Industri Pangan. 9 (2): 105-110.

Srivastava, S., Desai, P., Coutinho, E. and Govil, G. 2006. Mechanism Of Action Of Arginine On The Vitality Of Spermatozoa Is Primarily Throug Increased Biosynthesis Of Nitric Oxide. Tata Institute of Fundamental Research.India. (74) hal 954-958.

Zade, V.S., Dabhadkar, D.K., Tharake, V.G. and Pare, S.R. 2013. Effect of Aqueous Extract of Moringaoleifera Seed on Sexual Activity of Male Albino Rats. Biological Forum-An International Journal, $\quad$ 5(1): 129-14. 
23 / Aristiani, P., Sutyarso, Busman, H. 